\title{
SOUTHERN SYMPATHIZERS IN IOWA DURING CIVIL WAR PERIOD
}

\author{
By Frank C. Arena, A.B.*
}

\section{FOREWORD}

Traditionally Iowa has been considered a northern state, both in terms of geography and sympathies. What transpired during the Civil war years was quickly forgiven and forgotten. This was almost universally true within Iowa, where after the cessation of hostilities, the Southerner was entirely absorbed and took on the point of view of the average Iowan. This re-processing has become so effective that today most histories of Iowa and recollections of Iowans of the Civil war era forget the southern influence that existed in Iowa during the rebellious years.

Many histories disregard the flurry of disturbances caused by Southerners, passing over it as a blot on the record of Iowa's proud history. It is ironic that Americans for the sake of unity are quick to forgive and forget inhumanity visited upon them by other rebellious Americans. They are not so quick to forgive and forget what the Indians did. As a result, we have a vivid picture of the Indian problem; but, as for the southern sympathetic white who created great embarrassment for the pronorthern Iowan, all is forgiven, or at least forgotten.

So much has been forgotten that very few ever imagine that Iowa contained southern born or southern sympathizers. However, there were many Southerners within Iowa prior to and during the Civil war. They were in sufficient numbers to cause unrest, uncertainty and feeling of insecurity.

In order to get a true and conclusive picture of the

\footnotetext{
*Mr. Arena resides in Davenport, Iowa, a graduate of St. Ambrose college there, receiving his degree in 1949; entered Drake university, Des Moines, in February, 1950, in the department of history and government, doing work to receive his M.A. degree. This article is a condensation of his master's thesis, submitted in partial fulfiliment of the requirements. As a member of the U.S. army reserve, with rank of captain, he was recalled to the armed forces in August, 1950.
} 
state of affairs in Iowa during the Civil war years, it is necessary to deal with some primary sources. The state census records in the files of the Iowa State Department of History and Archives at Des Moines, indicate if the Southerner came to Iowa, and in what numbers. The house journals of the State General Assembly tell more than just the reporting and voting upon house files. By considering the type of bill and who voted for it, one is able to draw a picture as to what interests were being served. Lastly, by examining the newspapers of the Civil war period, one finds on-thespot reporting dealing with attitudes and actions of those who stood apart from those who were dedicated to the perpetuation of the Union.

These primary sources reveal how numerous and how active were the southern sympathizers in Iowa during Civil war times.

\section{The SOUTherner Comes to Iowa}

Iowa, as a traditional northern state, in her early days was visited, explored, and to a definite degree governed by some who were truly southern. The problem of an early community called for governmental supervision during the transition from untamed Indian land to statehood. The presence of army units, between 1821 and 1834, was primarily to see that the Indian kept the peace. The establishment of Fort Madison in southeastern Iowa was authorized there so that the Indian tribes, the Sacs and Foxes, would be forced to carry out the provisions of their peace treaties with the white man. Half-breed land tracts, particularly in Lee county, were cleared of Indians so that the area would be made ready for the white settlers. Another reason for the presence of army troops was to supervise the relations of the Indian and the lead miners in the vicinity of $\mathrm{Du}$ buque, Iowa, and Galena, Illinois.

There was a very high percentage of southern-born among the Iowa army officers. One of the first officers 
in the area was a Col. Willoughby Morgan, ${ }^{1}$ a Virginian by birth, whose duty it was to represent federal authority among the Galena miners. The same class of workers in the vicinity of Dubuque long remembered a Virginian by the name of Col. Zachary Taylor who was sent there to quell any disorder. This was the same Zachary Taylor who one day was to become president of the United States. During the Blackhawk war, in the early 1830's, Lieut. Jefferson Davis was in the area fighting against the Indians. Davis also found himself associated with Col. Zachary Taylor, and married his daughter. There were many other men of southern birth in Iowa at this time, among whom was Robert $\mathrm{E}$. Lee, and one must not forget the large, but unknown, number of enlisted men. To what extent these army officers and enlisted men of southern background influenced southern emigration into Iowa probably will never be known.

With regard to explorers in the area, it should be sufficient to name two of the more renowned. One, a North Carolinian by the name of Lieut. Albert Lea, ${ }^{2}$ made a report on his exploration throughout Iowa which prompted the establishment of the second Fort Des Moines. Lea made a thousand-mile jaunt through the Des Moines and Skunk river valleys, and then on along the Raccoon fork. His writings took the form of a diary which described Iowa and its natural resources in such glowing accounts that many were influenced to settle there. The success of Lea's exploration, in a large measure, was due to the presence of a Kentuckian named Capt. Nathan Boone, youngest son of Daniel Boone. Here it is seen that two famous explorers in early Iowa history were of southern origin. Students of history are still faced with the unanswered question of just how

1F. I. Herriott, "Whence Came the Pioneers of Iowa," ANNALS of IowA, vir, (1906), 454. Professor Herriott provides information as to early leaders in Iowa. Mention was made also of Col. Zachary Taylor, Lieut. Jefferson Davis, and Robert E. Lee.

${ }^{2}$ Albert M. Lea, The Book That Gave To Iowa Its Name, (Iowa City: State Historical Society of Iowa, 1935). 
much were these men responsible for Southerners coming northward into Iowa.

\section{SOUTHERNERS INFLUENTIAL IN IOWA}

Within the realm of politics and government, a look at the record shows a surprising number of southern-born who were influential in Iowa. Jesse B. Browne, ${ }^{3}$ supposed to have been one of the first merchants in Keokuk, was a Marylander by birth. He had the distinction of being the first speaker of the territorial House of Representatives which convened in Burlington, December, 1838. Charles Mason ${ }^{4}$ of southern birth, was for many years a judge of the Iowa Supreme court and had the added distinction of writing the Iowa code in 1851 .

Many Indian agents were stationed in Iowa before and during territorial days. With the Blackhawk treaties of 1832, the West was opened for the settlers. This meant the need for Indian agents to protect the Indian against the white trader and settler and sometimes vice versa. Iowa, being at the crossroads leading to the West, had need for many of these government agents. One such famous and noteworthy Indian agent of the federal government was Joseph M. Street. He had the duty of supervising the Indians in Iowa and Wisconsin and was known as "a grand old Virginian." Through his untiring efforts, the policy of mission schools for the Indians was established. Many other prominent Iowan names of southern origin may be given, such as Henry Dodge, who as governor of the Wisconsin territory was also governor of Iowa, then a part thereof. Though a native of Indiana, he spent his youth in Kentucky and began his political career in Missouri.

In 1838, the First Territorial Legislature of Iowa met at Burlington. At this meeting there were twenty Southerners, five New Englanders, eight from the middle states and five from Ohio and Illinois. All twenty of

\footnotetext{
${ }^{3}$ F. I. Herriott, "Whence Came the Pioneers of Iowa," ANNALS of IowA, VII, (1906), 452.

${ }^{4}$ Ibid., 453.
} 
these Southerners were born below the Mason and Dixon line and were not simply of southern extraction. In the senate of the Third General Assembly of Iowa in 1851, Southerners numbered seven as against two from New England. In 1854, ten state senators out of eighteen were southermers. ${ }^{5}$

Some prominent southern names in Iowa's history are better known than others. For instance, of Iowa's first three territorial governors, two were of southern birth. Among the lesser-known names, but by no means insignificant, James Grant stands forth. ${ }^{\circ}$ Grant was born in North Carolina in the year 1812. In 1841 he was elected from Scott county, Iowa, a member of the house of representatives in the Fourth Territorial Assembly. In 1844, he was elected to the First Constitutional Convention, and in 1846, to the Second Constitutional Convention. In both sessions he drew up the section embracing the Bill of Rights. Grant was elected a member of the Assembly from time to time. G. C. R. Mitchell was another of the lesser-known leaders. Born in 1803, in Tennessee, he was elected in 1843 to the house of representatives of the Iowa Territorial Legislature. In 1846 he was an unsuccessful candidate for congressional representative of the Territory of Iowa."

Clabourn C. Wilson, a Kentuckian by birth, was the type of man who was not known outside his own community. The city of Keokuk will probably long remember this man, who as a doctor rendered great service to his community. He headed the county medical society as well as that of the state. ${ }^{8}$

Presley Saunders, another Kentuckian, was the first settler in the community now known as Mt. Pleasant, and was probably the most instrumental promoter of its establishment.

Even some of Iowa's generals during the War of the Rebellion were Southerners. Generals John Edwards

5See table 1 for comparative members.

${ }_{\mathbf{R}}$. Tuttle, History of Iowa Illustrated, (Chicago: Peale \& Co., 1876), 670.

TIbid., 689 .

IIbid., 718.

IIbid., 723. 
and James A. Wilkinson, both Kentuckians, won high regard in Union military circles. ${ }^{10}$

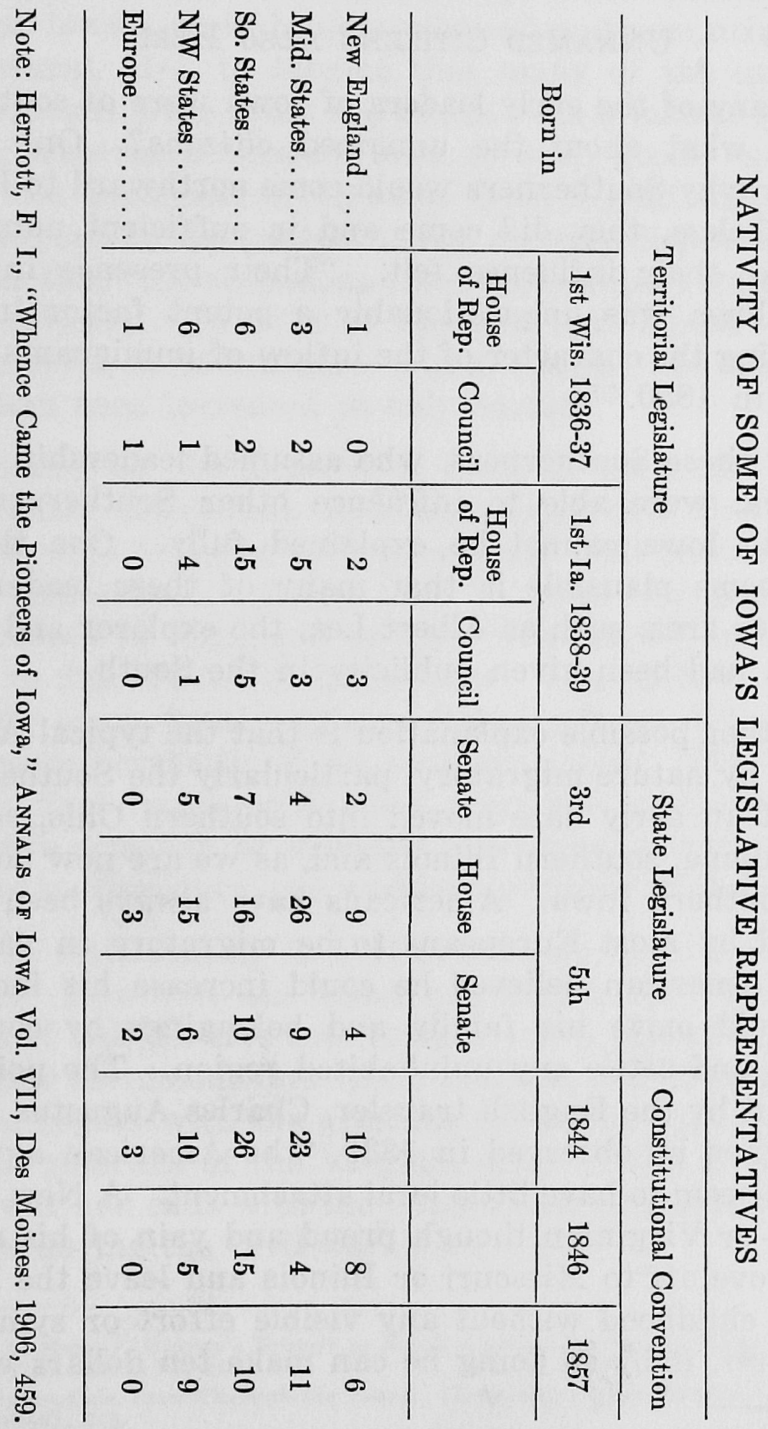

10Ibid., 676. 
The evidence is clear that Iowa was early subjected to the influence of southern leaders who mapped out her land, quieted the Indians, governed her new communities, and even led her citizens in the Civil war.

\section{Unnamed Citizens Also Here}

If many of the early leaders of Iowa were of southern origin, what about the unnamed citizens? One may wonder why Southerners would come northward to Iowa. Nevertheless, they did come and in sufficient numbers to make their influence felt. "Their presence in and about Iowa was unquestionably a potent factor in determining the character of the inflow of immigrants that began in 1830."

How these Southerners, who assumed leadership roles in Iowa, were able to influence other Southerners to come to Iowa cannot be explained fully. One theory that seems plausible is that many of these leaders in the Iowa area, such as Albert Lea, the explorer and map maker, had been given publicity in the South.

Another possible explanation is that the typical American is by nature migratory, particularly the Southerner, who at an early date moved into southern Ohio, southern Indiana, southern Illinois and, as we are now noting, into southern Iowa. Americans have always been considered by most Europeans to be migratory in nature. If an American believed he could increase his income, he would move his family and belongings by covered wagon and settle any uninhabited region. The point is best put by the English traveler, Charles Augustus Murray, when he observed in 1839, "the American agriculturists seem to have little local attachment. A New Englander or Virginian though proud and vain of his state, will move off to Missouri or Illinois and leave the home of his childhood without any visible effort or symptom of regret, if by so doing he can make ten dollars where

\footnotetext{
454 .

11F. I. Herriott, "Whence Came the Pioneers," Annals of IowA, VII, (1906),
} 
he before made eight. I have seen such repeated instances of this, that I cannot help considering it a national feature." ${ }^{\prime 2}$

As has been indicated previously, a considerable number of Iowa's early leaders were of southern origin. It is natural, also, to assume that many of the unnamed immigrants were from the South. As a matter of fact, the Southerners entered Iowa in such goodly numbers that the argument of Cyrenus Cole, a politician of the period, can be neutralized if not entirely disproved. Cole claims that "the accessions from the southern states were insignificant. In 1850 it appears that 30,945 Iowans were listed as of southern origin, and in 1860 this number had been increased to only 54,006.",13

Because of the location of Iowa in the midst of the continent, native-born American emigrants flowed into her borders bringing with them their local political ideas and dispositions. From 1836 to 1860, the population "increased by leaps and bounds, from 10,531 in the former to 673,779 in the latter year. The earliest settlers chiefly came from southern Ohio, Indiana, Illinois and the more northerly of the southern states. The bulk of these first immigrants came from the southern states or were remotely of southern extraction, settling mostly in the southeastern and southern portions of the state." ${ }^{\prime \prime}$

This statement by F. I. Herriott may be questioned by some. However, one must not forget that the movement of Southerners into Iowa is but a logical extension of their movement into Ohio, Indiana, and Illinois. Evidence begins with the granting of bounty lands in Ohio to the veterans of the Virginia army of the Revolutionary war and ends with the Copperhead problems in those states during the Civil war.

${ }^{12} \mathrm{C}$. A. Murray, Murray's Travels in North America During the Years 1884-1836. (New York: 1837), I, 148.

${ }^{13}$ Cyrenus Cole, Iowa Through the Years. (Iowa City: State Historical Society of Iowa, 1940), 213.

${ }^{14} \mathrm{~F}$. I. Herriott, “The Transfusion of Political Ideas and Institutions in Iowa, ANNALS OF IOWA, VI, (1903), 47. 


\section{EARLY IOWANS 6 To 1 From SOUTH}

It has been estimated by one investigator that prior to 1850 "Iowa people who had come directly or indirectly from the South are said to have outnumbered the New Englanders in the state by 6 to 1.,"15

Those emigrants with southern sympathies coming from Ohio, Indiana, and Illinois were originally from Kentucky, Tennessee, and Virginia, or, at least, were descendants of those who came from the southern states. There is no practical way of calculating the extent of their influence in Iowa. However, F. I. Herriott in his "James W. Grimes versus Southrons" may be correct when he makes the statement that "the emigrants from southern and western Pennsylvania, from Ohio, Indiana, and Illinois were likewise southern in their ancestral inheritance, either by direct descent, or by reason of communal associations in life or trade."18 These pioneers settled the forest districts of Ohio, Indiana, Michigan, and Kentucky. Later they crossed over into the Illinois area. Kentucky and Tennessee contributed rather large groups to Indiana and Ohio, which even later furnished the population from which Illinois and Missouri could draw. This made it only natural for bordering areas to draw upon the population of their neighbors. Therefore, it was no phenomenon that Iowa and, for that matter, Missouri, drew upon their neighbors for their population.

The situation is best described by George F. Parker when he states that "Kentucky and Tennessee thus sent numbers into Ohio and Indiana which in turn furnished from their scant quotas a goodly proportion to Illinois and Missouri. In fact, then was begun that movement of people now forth, now back and again back and forth, all so turning upon their own tracks that the currents of population became more and more human eddies."17

\footnotetext{
${ }^{15}$ Robert Y. Kerr, "Iowa Historical Record," Iowa Journal of History and Politics, XXIV, (1926), 295.

${ }^{16}$ F. I. Herriott, "James W. Grimes versus Southrons," ANNALS of IowA, XV, (1925), 329.

${ }^{17}$ George F. Parker, Iowa Pioneer Foundations, (Iowa City: State Historical Society of Iowa, 1940), I, 78.
} 
Many of these people moved westward, and when Iowa was opened for settlement by the Blackhawk treaty, located in the southern counties because Lee, Des Moines, Louisa, Scott, Muscatine, Van Buren, and Davis counties had popular river crossings and ferryboat facilities. Many of the Southerners stayed on in the southern counties because it looked like good land to them, lightly populated and near rivers. Some of those who had settled in Missouri previously found or heard of the abovementioned attractions and moved northward, being satisfied with the better soil just north of the Iowa border.

\section{State Census Shows Nativity}

The clearest and most tangible evidence of the presence of Southerners in Iowa is to be found in the state census taken in 1856. Here is shown the distribution of southern born. Obviously some who came from southern Ohio, Indiana, and Illinois retained many of the points of view of their southern ancestors. However, they cannot be separated numerically from others who came from those states.

By 1856, the three counties having the highest percentage of southern born were Mills, Taylor, and Dallas, each having thirty-one per cent. In Mills, of the southern population, 426 came from Missouri. Virginia sent 162, while Kentucky sent 177; and Tennessee furnished a large number, 119. There were other sprinkling groups from Arkansas, Texas, Alabama, Louisiana, North and South Carolina, and Maryland, making a total of 946 southern born in a total population of 3,102 . In Taylor county, Missouri again sent the largest number, 222. However, Kentucky was not far behind with 189. Tennessee sent 113, and Virginia 68. The rest of the thirty-one per cent was made up of people from Arkansas, Texas, Alabama, North and South Carolina, Mississippi, and Georgia, the total numbering 641 Southerners of a population of $2,079 .^{18}$ A plausible explanation for

\footnotetext{
${ }^{18}$ State of Iowa, Census Reports of 1856, House documents and appendix to House of Representatives Journal, (Iowa City, 1856). All census data, including percentages and origin of Iowa population, were obtained from the above-quoted source.
} 
so large a number of southern born in Mills and Taylor counties is the proximity of Missouri, which sent the largest delegation.

Dallas county in the central portion of the state was the third area holding thirty-one per cent of southern born. Here evidence shows that of a total population of 2,832 there were 866 Southerners. Unlike Mills and Taylor counties, the majority of Southerners came from Kentucky which sent 308 settlers. Next highest was Virginia with 192, North Carolina, 186, and Tennessee, 122. The rest of the southern population was made up of Alabamans, Louisianans, South Carolinians, Mississippians, Georgians, and Marylanders. Possibly the distance of Dallas county from the Missouri border accounts for the fact that another state was the chief source of its southern-born citizens.

No doubt the reason for Greene county having an eighteen per cent southern population was because of the fact that it lay just north of Dallas and was influenced by whatever factors brought so many Southerners to that region. As Dallas county drew most of its southern population from Kentucky and Virginia, so did Greene county, for Virginia, Kentucky, and North Carolina sent more settlers there than did any of the other southern states.

Fremont county, which lies at the southwestern tip of the state, with a twenty-eight per cent southern population, presented a situation very similar to that of Mills county. Of the Southerners in Fremont county, 361 were Missourians; Kentucky had sent 241, and Virginia, 169. The rest of the total of 941 Southerners of a population of 3,368 came from Arkansas, Alabama, North and South Carolina, Tennessee, Georgia, and Maryland. For the proportion of Missourians in Fremont county, there would seem to be the same explanation as in Mills county, namely, proximity to Missouri. Pottawattamie county just above Mills likewise had a similar distribution of southern origins. Although its southern popula- 
tion was but thirteen per cent, or 461 of a total of 3,498 , its main southern emigration came from Missouri, Virginia, and Kentucky in the same proportions as in the case of the other counties.

\section{Border COUnTIES SHowed Similarities}

Throughout all of the southern border counties of Iowa running from Lee westward to Fremont, there are striking similarities in the make-up of the southern element within these counties. For instance, to Page county with twenty-six per cent of the population southern born, Missouri contributed the greatest number, 139. However, Kentucky was second with 130 , then Tennessee followed with 117, and Virginia with 64 . The rest of the total 514 southern settlers came from Arkansas, North and South Carolina, Georgia, and Maryland; the total population was 1,964. A similar situation existed in Decatur county with a twenty-three per cent southern population, Missouri, Kentucky, Virginia, and Tennessee sending 1,304 of the total of 1,447 settlers.

In Wayne, Appanoose, and Davis counties the figures varied slightly, yet the bulk of the population came from the same southern states and in the same proportions. As in the counties already discussed, to Wayne county with twenty-six per cent of its population coming from the South, Virginia furnished 403, Kentucky 267, North Carolina 159, Tennessee 120, and Missouri 90. The rest of the southern states accounted for the remainder of the 1,070 Southerners living in that county having a total of 4,183. Appanoose with twenty-two per cent of southern nativity presented a very similar situation, Virginia sending 514, Kentucky 533, Tennessee 436, North Carolina 267, and Missouri 170 . Southerners from these states comprised 1,920 of a total of 2,021. Davis county with twenty-three per cent of its population of southern origin had 941 from Kentucky, 639 from Virginia, 420 from Tennessee, 200 from North Carolina, and 307 from Missouri, totalling from all southern states 2,671 of an over-all population of 11,528. Van Buren county, al- 
though having only fourteen per cent southern population, received its bulk of Sotuherners from the same southern states, namely 993 from Virginia, 548 from Kentucky, 181 from Missouri, 133 from Tennessee, and 86 from North Carolina-in all, 1,941 of the total of 2,198 Southerners living in a county with a population of 15,921 .

The relatively moderate figure of fifteen per cent of Southerners in Jefferson county suggests that it may have been influenced by the same factors that influenced the surrounding counties of Keokuk, Wapello, Mahaska, Henry, and Washington. All the above-mentioned counties had similar percentages and drew their southern population from the same sources.

Most of the counties above the southern tier had a percentage of Southerners ranging from thirteen to eighteen per cent, with the exception of Montgomery with twenty-six per cent and Mills with thirty-one per cent. Montgomery had a southern population of twentysix per cent with the greater number coming from Kentucky, Missouri, and Virginia. There were 165 southernborn in Montgomery county which had a total population of 625. Cass, Shelby, and Audubon counties, which are farther to the north, had a southern population of twelve or thirteen per cent. Jasper, considered a central county, had a rather high figure of sixteen per cent with most of her southern-born coming from Virginia, Kentucky, North Carolina, and Tennessee.

\section{Percentages Less to the North}

Moving further north in the state, the percentages of southern-born tend to become smaller, with the exception of such counties as Hardin with nineteen per cent of southern nativity, Marshall with twelve per cent, Poweshiek with eleven per cent, Mahaska with fourteen per cent, and Keokuk with fifteen per cent. The distribution of origin in three of these counties is similar. For Hardin, the 1856 census reports show that Virginia, 
Kentucky, North Carolina, and Tennessee sent a total of 727 of 759 Southerners. Within the borders of Marshall county, the same story prevailed, with Virginia, Kentucky, North Carolina, and Tennessee sending a total of 445 of 516 Southerners. Poweshiek county gave the same type of population figures with 409 of a possible 504 southern-born coming from Virginia, Kentucky, North Carolina, and Tennessee. The figures are interesting in that they show that these counties which lie near one another tend to have very similar population proportions, suggesting that people of like origin and like points of view were inclined to settle in the same community.

Polk county, although next to Dallas, in the central part of the state, with a twelve per cent southern nativity, had about the same distribution as Marion and Wapello counties. Virginia sent to these three counties 1,428, Kentucky 1,727, North Carolina 471, and Tennessee 618 , totalling 4,244 of 5,080 Southerners living there. It may be added that these three counties had a total population of 37,123 with an average of fourteen per cent southern born.

The more northerly counties of the state, as has been mentioned, had negligible numbers of Southerners. No doubt this is due to the fact that throughout the history of the country the tendency has been for the population to move on an east-west line with little deviation to the north.

By the state census of 1856 , the total population of the state of Iowa was 507,863 , while the southern-born of the state numbered but 52,595. Between 1856 and 1860 little change took place in the number of southernborn. In 1860 the total number had increased to but 54,006 . This would show an increase of southern-born in Iowa of $1,411 .^{10}$ The Federal census for 1860 does

\footnotetext{
19The records of the state census of 1860 do not show usable summaries and are not as complete in details as those of 1856. They are here used to show the increase in total population. It is assumed that the proportion of southern-born in Iowa did not increase.
} 
not permit a breakdown of totals into the same categories as does the state census of 1856 . However, significant changes in proportions can hardly have taken place.

\section{THE NEGRo IN IOWA}

A further point of interest relates to the presence of a Negro population in Iowa. It might logically be suspected that the "underground railroad" would bring a considerable number of Negroes into the state who would have been classed among the southern-born. This seems not to have been the case, for although Negroes were smuggled into Iowa, they did not remain long. The object of freeing the slaves was to get them out of the country and into Canada. The number of Negroes in Iowa by the 1856 census totaled approximately 255, with the majority being native born.

Dubuque had a rather relatively large number of $\mathrm{Ne}$ groes, approximately 36 . This was possibly so because of the mining within that county. Fayette county had 44 Negroes, possibly for the same reasons. The three lower tiers of counties, running east to west, embraced 31 counties. Sixteen of these counties had a total of 119 Negroes. Of the rest of the state of Iowa, embracing 68 counties, eleven counties accounted for 136 Negroes. Even if the 255 Negroes in Iowa noted by the 1856 census were counted as southern-born, the percentages of Southerners would not be altered to any appreciable extent.

The number of southern-born in Iowa does not adequately indicate the strength of southern sentiment then existing. There were others in Iowa with similar points of view, those who came indirectly from the South, through Ohio, Indiana, Illinois, and even through western Pennsylvania. The state of Iowa census of 1856 shows in detail the nativity of residents of the several counties. What the census fails to report is the ancestry of settlers in Iowa who had migrated from Illinois, Indiana, Ohio, and western Pennsylvania. The background 
of the people who migrated from these parts must have been, to a considerable extent, of southern origin. Some of these settled in southern Iowa. The large number of southern sympathizers in Iowa moved Governor Stone to remark in a letter to Secretary of the Treasury Salmon $P$. Chase that "the southern half of our state is strongly pro-slavery, but I think we will be able to carry a majority with us for free principles. The north third of our state will be to Iowa politically what the Western Reserve is to the state of Ohio."

What was implied in the above quotation is plain. Governor Stone brought out that the southern half of the state of Iowa showed outright southern sympathy. This could not have been the case with only 54,006 southern-born people in Iowa. In Governor Stone's mind those of southern lineage must have been included with those born in the South. This situation is further evidenced by the fact that Governor Stone implied also that if abolitionists or anti-slavery men of Iowa expected to foster their way of thinking and bring an end to the existence of slavery, they would probably have to do so without the aid of most of the people living in the southern half of Iowa.

It might be added that the three states of Ohio, Indiana, and Illinois sent a very sizeable population to Iowa, numbering $162,847 .^{21}$ It is difficult to determine how many of these were from southern Ohio, Indiana, and Illinois, for these areas were populated by people of southern lineage. If these figures were obtainable, one would have a very conclusive picture of the number of people with southern sympathy, living in Iowa. Those of southern lineage must have been in considerable numbers in those areas for, as Governor Stone implied in his letter above quoted, the number of Southerners coming from southern Ohio and other states to the East was large and possessed political power.

\footnotetext{
${ }^{20} \mathrm{~F}$. I. Herriott, "Whence Came the Pioneers of Iowa," ANNALS of Iowa, VII, $(1906), 462$.

21State of Iowa, Census Report of 1856, House documents and appendix to House of Representatives Journal, (Iowa City, 1856).
} 


\section{SetTlers Brought Their Beliefs}

Iowa, by her geographical location, was at the crossroads of a continent. She received within her borders settlers from other states who brought with them their own peculiar political inheritances. Southern emigration made itself shown by the extremely conservative views prevalent in the southern part of Iowa. Having been accustomed to the county form of government in the southern states, these emigrants felt that the citizens should be dealt with in large and loosely-organized units. They felt that the barest minimum of government was all that was necessary. All they asked was just enough government to enforce the laws for the protection of life, liberty, and property and the maintenance of the courts, feeling the less government, the better. Even education and the care of institutions for the insane were considered matters to be looked after by the individual directly concerned.

These and similar views were those held by the southern elements in Iowa; and these were the notions with which Iowa governors had to contend. Governor Chambers was moved to remark "how little interest the important subject of education excites among us." ${ }^{22}$ The same opposition appeared when grants were requested for local and state libraries. This viewpoint prevailed in the South and was brought by the Southerner when he settled Iowa. As a matter of fact, this characteristic point of view predominated in Iowa from 1851 to $1860 .^{23}$

The basis of southern points of view in Iowa before and during the Civil war is to be found in the fact that the Southerners were here. Likewise, people of southern point of view coming from Illinois, Ohio, Indiana, and western Pennsylvania also settled in southern Iowa, although their numbers cannot be set forth statistically. With the known number of southern born and an unde-

${ }^{22}$ F. I. Herriott, "The Transfusion of Political Ideas and Institutions in Iowa," ANNALS OF IOWA, VI, (1903), 52.

${ }^{2}$ F. I. Herriott, "Whence Came the Pioneers of Iowa," ANNALs of Iowa, VI $(1903), 373$. This article by Professor Herrictt, as well as the one cited above, contends that southern patterns of life were strong in Iowa before and during the Civil war period. 
termined number of people of southern extraction present in Iowa, it is illogical to suppose that they would remain silent.

$\begin{array}{cccc}* & * & * & * \\ & \text { II } & & \end{array}$

\section{The Southerner in Iowa Speaks His Mind}

No group of people with such a definite point of view as that which characterized the southern mind, could be expected to remain silent. Living in a northern state might in itself serve as a check on them, as might also the fact that they were in a minority. Nevertheless, these Southerners found a very logical way to express themselves. The southern sympathizer in Iowa spoke his point of view through the effective means of his representatives.

It is no wo der that the counties in Iowa, having a relatively high number of Southerners, sent their own type of representatives to the state government to express their interests and sympathies. In pursuing this point it is best to examine the house of representatives of the Iowa General Assembly, rather than the senate, for by so doing one is able to get a more exact picture of the sympathies of these communities with southern interests.

When the Eighth General Assembly met on January 8,1860 , there were 34 Democrats and 53 Republicans in the house of representatives. This indicates a decline of the Democratic party in Iowa, for prior to the middle 1850 's, the Democratic party more times than not had control of either or both houses of the state legislature. In the middle 1850 's a very evident decline of the Democratic party's strength was revealed, even in the gubernatorial races. This decline in party strength can probably be explained by the fact that in the 1850 's the slavery problem then gripped the nation as it never had before. 
The Kansas-Nebraska bill in 1853-1854 was the fuse that set off the dynamite. The beginning of the new Republican party was an event that gave evidence of a change in political sentiment. In Iowa as in the rest of the nation, this party was organized primarily by exWhigs disgusted with earlier party associates who voted for the Kansas-Nebraska bill. Some of the Iowa Democrats were not hesitant to show that they would accept a compromise with slavery, although few would go as far as the southern Democrats, many of whom insisted on the free extension of human slavery. Suffice it to say that the new Republican party was going to take a view opposing both the moderate and the extreme Democrats. It was their intention to form a group with a balance of power, though they preferred to completely overwhelm the Democratic party and its point of view.

The northern portion of the United States, having anti-slavery attitudes of one type or another, readily accepted the new anti-extension phase of slavery regulation. It must be emphasized here that the new Republican party, of which Abraham Lincoln was an early leader, was not at first wholly an abolitionist movement. It was against the extension of slavery into any territory or newly-admitted state. During these troubled 1850's, Republican strength constantly increased in the North. This was the situation in Iowa, where also the decline of the Democratic party became very evident by 1860 , when the Eighth General Assembly showed a clear margin of majority for the Republicans. Party issues were constantly growing clearer. The Republicans insisted upon no further extension of slavery; eventually the party espoused abolition. The Democrats defended the existing property rights in slavery.

\section{Clash Carried to Legislature}

The Iowa counties having the higher percentages of southern-born sent Democrats to the legislature to speak their mind on this slavery question. According to S. H. M. Byers, the greatest troublemakers in this respect 
were the Democratic representatives from Boone, Wayne, Marion, Keokuk, Des Moines, Page, Fremont, Wapello, Madison, Delaware, Jackson, Pottawattamie, Appanoose, Jones, Van Buren, Dubuque, Louisa, Lee, Warren, and Davis. These counties contained from six to thirty-one per cent of southern-born immigrants. A considerable proportion of the above-named counties was close to the thirty-one per cent margin. ${ }^{24}$

It was no accident that with the decline of the Democratic party in most of Iowa the counties with many southern born still elected pro-slavery Democrats. Their convictions were unchanged, although their numbers were fewer.

These counties of Iowa with southern sympathies were consistent in their voting for national officers, as shown by the results of the congressional elections of 1860 in the first district in Iowa. The two candidates were Samuel R. Curtis, Republican, and Chester C. Cole, Democrat. The Democratic candidate received a clear majority in almost every county where a high percentage of Southerners resided. To illustrate, in Appanoose county, Curtis received 870 votes to Cole's $1,261 .^{25}$ The total district vote was 33,936 for Curtis, while Cole polled only 30,246 .

In the 1860 gubernatorial race between Samuel J. Kirkwood, the Republican, and Augustus C. Dodge, the Democrat, a very similar situation arose. Dodge's chief support came from those counties having the high percentage of southern born. Although he lost the election by 3,200 votes, the distribution of returns left no doubt who supported Dodge. This campaign between Kirkwood and Dodge presented very clearly the issues and the positions taken by the two opposing groups in Iowa. A typical debate between these two gubernatorial aspirants took place in Oskaloosa prior to the election in 1860.

\footnotetext{
48.

${ }^{24}$ S. H. M Byers, Iowa In War Times, (Des Moines: W D Condit \& Co, 1888), ${ }^{45}{ }_{25}$ B. F. Gue, History of Iowa, (New York: The Century History Co., 1903), IV, 56-57. Incidentally, Cole later repudiated his Democratic position and joined the Republican party.
} 
Both Kirkwood and Dodge were leaders of their respective political parties, so that what was said or advocated by each usually had party endorsement. Mr. Kirkwood began by condemning the Dred-Scott decision and hitting at the evils of slave labor. Mr. Dodge replied, with references to the Kansas and the LeCompton constitution, that the Fugitive Slave law was part of the constitution. Dodge tried to put Kirkwood on the defensive, then asked if he, Kirkwood, supported the compromise measures of 1850. Mr. Kirkwood's answer was that he accepted the majority of the people's wishes and this was their choice of measures to settle the slavery question.

"Mr. Dodge then asked if he would aid in carrying out the fugitive slave law. Mr. Kirkwood replied that he would not resist the enforcement of that law, but he would suffer the loss of his right arm, and every dollar's worth of property he possessed, rather than aid in catching a fugitive slave.",2

Mr. Dodge put himself on record as willing to enforce stringently the fugitive slave law, adding that he himself would take part in tracking down any runaway slaves.

In summation, Mr. Dodge claimed that his opponent "had depicted slavery in its worst aspect. Dodge declared that slavery in its influence on the blacks was Christianizing and civilizing; that the Negroes were brought from the jungles of Africa, and in this country were enlightened, Christianized and prepared for heaven. In old times, continued he, when a slave ship from Africa reached our shores, the Negroes were welcomed with open arms because the people realized that another cargo of human beings was saved from heathenism and perdition.,"27

\section{Personal Bias Deep-Seated}

Such debates reveal more than conventional party distinctions. They represent deep-seated personal convic-

\footnotetext{
${ }^{26} \mathrm{H}$. W. Lathrop, The Life and Times of Samuel J. Kirkwood, (Iowa City: State Historical Society of Iowa, 1893), 70.

27Ibid., 71.
} 
tions. The Southerners living in Iowa were opposed to slavery being brought into this state. They had escaped it by moving westward into frontier and unsettled regions. It was slavery that caused their plight. Yet these southern-born and of southern extraction never entertained the thought of freeing the slaves of others. To them such action meant the utter destruction of private property. Although they believed the slaveholder had a perfect right to take his slave wherever he wanted, yet they did not want the institution of slavery to envelop them. Equality of Negroes was something else that could never be tolerated by these Southerners living in Iowa. They honestly believed that the Negro was cursed into bondage and was as a result the only one capable of doing hard physical work. To them this institution was as much American as our constitutional form of government. They were going to protect this tradition by every constitutional means, namely, by sending representatives to the state government that were friendly to the slavery tradition as they saw it.

Let us now turn to the functioning of the state government during the troubled times of 1860 to 1865. As mentioned earlier, the Democratic party power was declining in strength in Iowa as the war years approached. In the Eighth General Assembly, in the house of representatives, the number of members from the Democratic party had declined to thirty-four of a possible eightyeight members, for a number of reasons. As the northern half of the state became more and more densely populated, the type of person coming into Iowa was predominately of northern background. Also, the European immigration (particularly Germans, Norwegians, and Danes) was flowing in quite rapidly. With the increase of population, more counties were formed which, in turn, created many new representative districts. Consequently, representation for the northern half of the state of Iowa increased relatively. Northerners with their anti-slavery background and Europeans with their knowledge of what submission to rule meant, looked for a political 
party which would not endorse or condone the human misery of slavery. That is why these two classes looked to the Republican party. Wherever these people settled, a Republican candidate was almost assured of election. This was the situation at the convening of the Eighth General Assembly.

When the Ninth General Assembly met January 12, 1862, there were four Democrats missing in the house of representatives. Although the house had increased by three districts, the Democrats had only thirty members, while the Republicans increased to sixty. The reasons for this situation are probably the same as mentioned above: more northerners as well as more Europeans coming into the state.

\section{STATE'S GROWTH HELPED UNIONISTS}

In the Tenth General Assembly, which met January 12,1864 , a very startling picture was presented when two new districts were added to the house of representatives. The members of the Democratic party decreased to five, and the Republicans or Unionists rose to eightyseven members. A look at the state population figures will eliminate any surprise at such a situation. From 1856 to the beginning of 1860 , the population rose from 519,055 to 638,775 , an increase of 119,720 . Between these years, the increase of Southerners in Iowa was but $1,411 .^{28}$ By 1864 the population was increased by 62,957 with the number of Southerners coming into the state being negligible. The greatest bulk of the increased population came from New England, the old Northwest, and Europe. So great was the immigration from the above-mentioned areas into all parts of Iowa that the percentage of southern-born living in southern counties mentioned in the first chapter steadily declined, although the actual number remained fairly constant. Such a situation might be explained in part by the fact that during the years from 1856 to 1860 , the South did not

\footnotetext{
${ }^{28}$ Cyrenus Cole, Iowa Through The Years, (Iowa City: State Historical Society of Iowa, 1940), 213.
} 
have a population that permitted it to match the migration from the North and from Europe. The European immigration into the United States settled in the North; the number that settled in the South could probably be counted on the fingers of one hand. Of the number of Southerners migrating westward, many went to other states. Whatever the reason may be for the small number of Southerners coming into Iowa from 1856-1860, one thing is certain: the high percentage of southernborn living in Iowa kept decreasing as the total population of the state increased.

From 1861 to 1865 , there was a very abnormal but understandable situation prevailing. During the Civil war years, there was no flow of emigrants from the South into Iowa. Even if great numbers had wanted to come to Iowa, they would have been unable to do so. There was no normal crossing of state boundaries then.

\section{Pro-Slavery Sentiment Persists}

In spite of decline in relative numbers, these Southerners in Iowa, whenever they were able, continued to send pro-slavery Democrats to the state legislature. Though these representatives were in the minority, they were able to needle the anti-slavery Republicans very often.

State legislatures are mostly concerned with legislating for local matters only. As a result, not much legislation is passed that will affect people outside the state boundaries. Most legislation is the drab routine passage of conventional bills. Consequently, during the Civil war years, few issues of national significance were directly involved in state legislative debate. There were certain directives from the Federal government which the state legislature was to facilitate, yet the anti-slavery Republican majority simply acted to put these directives into operation.

During these troubled years from 1860 to 1865, although the Democrats were a small minority, they, nev- 
ertheless, tried to sponsor such bills as were anti-Negro, and sometimes they withheld their support from the war effort. There were a few instances during the Eighth, Ninth, and Tenth General Assemblies when they made clear where their sympathies lay. Not much of their discussion was on major problems, for as noted earlier, the state legislatures were concerned with routine state matters. Yet during the Eighth, Ninth, and Tenth sessions of the house of representatives, interesting incidents occurred showing the anti-Negro sentiment of the Democrats from the southern counties.

These representatives sent by counties having the most southern-born were very prompt to show their proslavery sentiment. One of the most startling illustrations took place on January 11, 1860, when at the opening of the general assembly, Governor Kirkwood addressed the state senate and house of representatives expressing opinions that later prompted vigorous protests. ${ }^{20}$ The governor during the first half of his address gave an account of the conditions and affairs of the state of Iowa. During the last half of his speech, the governor let loose a volley of oratory upon the whole slavery problem. He first considered the attack of John Brown at Harper's Ferry. The governor acknowledged that it was an unlawful invasion of Virginia, but then he proceeded to give the underlying and moving causes that prompted acts of Brown and his misguided followers.

Kirkwood claimed that the slavery question had been quiet until March 4, 1853, when Franklin Pierce was inaugurated President of the United States. The first important act passed by the administration was the Kansas-Nebraska Bill. The avowed purpose of this "wanton, uncalled for, and most unfortunate act" wa was to settle the slavery question. By this act congress denied itself a power granted by the founders of the constitution, namely, the right to name the conditions under which a state enters the Union. According to Governor

${ }^{29}$ State of Iowa, House of Representatives, House Journal of the Eighth General Assembly. (Des Moines: State of Iowa, 1860), 54.

30 Ibid., 56. 
Kirkwood, whether the congressmen who voted were ignorant of the feelings of the people or just plain unfaithful, they, nevertheless, were faithless.

The debates in congress and the newspaper accounts over this bill were what caused the warlike excitement in Kansas. However, complete catastrophe was averted when the LeCompton bill was defeated. Kansas subsequently was admitted as a free state by her own wishes. Governor Kirkwood claimed a knowledge of these past events throw light upon the current events and circumstances. Men in Kansas who resisted the pro-slavery sentiment were treated without respect by the Federal government. Governor Kirkwood went on to claim that these pro-slavery friends would enforce their sympathies or views even at the expense of war. Kirkwood continued that, although we condemn the acts of John Brown, it was no wonder that he acted in this way with the conditions then prevailing. He continued that, although the acts stand condemned by most northern people, they, nevertheless, have a feeling of sympathy for John Brown, because of the conditions which prompted him and that the southern people in years to come will feel the same way.

There is no doubt as to the position of Governor Kirkwood. He acknowledged that John Brown was acting outside the law. He clearly implied that such occurrences were the natural result of the influence of proslavery Democrats upon the federal government. The Democratic representatives in the Iowa legislature responded at once.

\section{Protest KirKWOOD's SPEECH}

On February 1, 1860, a protest was submitted to the resolution authorizing the printing of 7,500 copies of the governor's address. The Democrats who voiced their opposition in the protest claimed that the "Inaugural Message of Governor Kirkwood, injurious both to the public and individuals, and firmly impressed with a con- 
viction, that a portion of said message is calculated to impair the harmonious relations which exist between the citizens of the several states."

The protest was stated with four points of emphasis. The first was mainly a protest that the reference of Governor Kirkwood to the invasion of Harper's Ferry by John Brown was nothing less than a personal opinion of the governor as to its causes. This lay outside his constitutional functions as a governor. By the constitution, a duty of the governor is "to communicate to the general assembly at every regular session, the conditions of the state and recommend such measures as he shall deem expedient." "sa To these protesting Democrats, there was no correlation between the causes that moved John Brown and the affairs of the general assembly. The absence of any recommendation to the general assembly as to legislation to be acted upon in this matter only further proved to these Democrats that the message of the governor with the authorization to print 7,500 copies for circulation was an attempt to circulate among the people a political speech at the expense of the state. ${ }^{33}$

The second part of the protest dealt with the fact that the governor's speech more or less condoned and excused the conduct of John Brown. The statement by the governor that "the mass of our northern people feel and express admiration and sympathy for the disinterestedness of purpose by which they believe he was governed," ${ }^{34}$ was challenged by the Democrats, who stated that while this may have been the opinion of the governor and the greater faction of his Republican party, it was not so with the majority of the northern people.

The third part of the protest was lodged against Governor Kirkwood's condemnation of ex-President Pierce and the members of congress who supported the KansasNebraska bill. This to the Democrats was a reprimand

\footnotetext{
31Ibid., 184.

32Constitution of Iowa, 1857

"State of Iowa, House of Representatives, House Journal of the Eighth General Assembly, (Des Moines: State of Iowa, 1860), 185.

${ }^{34}$ Ibid., 58.
} 
directed against their party which largely supported the measure. The protesting Democrats declared that there was no faithlessness on their part for as they were elected by the people, it was their prerogative to use the power conferred on them the best way they saw fit. The election of Buchanan, who endorsed the bill, was not the "cause of the Civil war in Kansas, the insurrection in Virginia, and the treason and bloodshed of John Brown",s as declared by Governor Kirkwood.

And in the fourth place, the Democrats protested that according to the implications of the Governor's speech, acts such as those of John Brown were to be approved when southern states did not conform to the standard of perfection as set by many of her northern neighbors.

The protest went on to attack the presumptiousness of the governor in implying that northern Democrats had been disloyal and to charge that it was messages such as his which caused the instability of the Union.

The protest was signed by every Democratic member of the Iowa House of Representatives, thirty-four in all. This opposition seems not to have been conventional party strategy, but mere jockeying for favorable position in the area of state politics. It was actual identifition on the part of Iowa Democrats with a large segment of dissident Southerners who were on the verge of secession. Even moderate Democrats were by implication drawn over into the violent group by this protest against Governor Kirkwood's address.

\section{Pro-Slavery Attitude Persists}

During this Eighth General Assembly, there were other incidents which showed the pro-slavery attitude of the Democratic party. One occurred on January 23, 1860, when a resolution was presented by State Rep. M. B. Bennett of Marion county, that a committee should be formed to look into amending the bill of rights of the Constitution of Iowa by submitting a proposition to the

35Ibid., 185. 
people of Iowa "to prohibit Negroes and mulattoes from

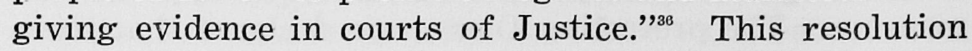
was most emphatically supported by all the Democratic members of the house of representatives. With the aid of a few sympathizing Republicans, the Democrats were able to get the resolution passed by forty-nine yeas to thirty-five nays. With the change in political complexion of the legislature, this proposed amendment died a natural death in the house committee.

Another illustration pointing out the pro-slavery or at least the anti-Negro sentiment occurred on March 30, 1860. The Republican representative from Scott county, Benjamin F. Gue, sought to amend an act which provided for a system of common schools. He wanted to insert "they (the counties and townships) shall provide for the education of colored youths in separate schools, when required by a majority of the legal voters of such districts." ${ }^{37}$ Representative Gue knew that as the law then stood, colored children were not allowed in white schools, and townships were not obligated to provide educational facilities for these unfortunate Negro children. By this amendment, local districts would be forced to provide for the education of colored children. Until that time a few white Iowans sought to educate Negro children in the privacy of their own homes.

Most of the Republicans backed this proposed amendment but the Democrats, with the aid of a few Republicans, were able to defeat the proposition by a vote of forty-eight to thirty-two, thus denying at this time education to all Negro children.

\section{James HaRlan Defeats Senator Dodge}

It fell to this Eighth General Assembly to elect a United States senator for the state of Iowa. In a joint session of the legislature, nominations were made to fill the office. James Harlan, a Republican, and Augustus C. Dodge, a Democrat, won the party nominations. The 
Republicans were able to elect Harlan for the senate seat. The Democrats without exception voted for the losing candidate. ${ }^{3 s}$ This action illustrated not only the party solidarity, but the type of man that the Democrats wanted in the United States senate.

The qualities and sympathies of Dodge during the gubernatorial race of 1860 have already been noted. Moreover, during the Civil war, this unsuccessful candidate for the United States senate had his loyalty to the Union seriously challenged. He was accused of being a Copperhead and having refused to take part in any way in the war effort. He refused to take a commission in the Iowa militia; he also refused to aid in the recruiting of soldiers. Patriotic speech, to give encouragement to the North, was never uttered by Dodge. Instead, he kept company with such men as Mahoney, publisher of the Dubuque Herald, a journal which constantly poured forth in print vigorous anti-Union sentiment. $\mathrm{Mr}$. Mahoney became so vehement in his denunciation of the Union cause that he had his printing presses smashed and he himself was jailed..$^{30}$

The Eighth General Assembly was characterized by another incident which occurred during the extra session in 1861. In May, the governor, in order to put the state on a war footing, asked the session to provide for a loan of $\$ 800,000$. Thirty-four Democrats voted against the bill. All the Republicans voted for it since they were unwilling to leave the state in a defenseless position. However, after over a week of hot debate, the $\$ 800,000$ loan was passed only to have its constitutionality challenged by the Democrats on the ground that the loan exceeded the limit on debt authorized by the constitution. $^{40}$

38Ibid., 80-81.

${ }^{30}$ Augustus C. Dodge was described by one newspaper as one who "refuses all aid or ccoperation to the cause of the Union. He will not take a commission when offered him. He refuses to encourage enlistments. He raises no voice against the rebellion. He attends no war meetings. He gives no money, no countenance, no recruits, to the loyal cause." (Burlington Daily Hawkeye, August 18, 1862). 48.

${ }^{40}$ S. H. M. Byers, Iowa in War Times. (Des Moines: W. D. Condit \& Co., 1888), 
When the Ninth General Assembly convened in Des Moines, January 12, 1862, there were four Democrats less in the house than had been in the previous session. They had been replaced by Republicans. Nevertheless, the Democrats still numbered thirty, enough votes to look impressive against any Republicans sponsored proUnion bill.

No more than five days after the house of representatives met in session, a joint resolution sponsored by Republicans was submitted asking for state action in the emancipation of slaves. ${ }^{41}$ The Republicans believed that with sixty votes they could push through such a bill. They decided to put the bill to a vote, but were greatly surprised when the thirty-four Democrats and eleven Republicans were successful in getting the bill shelved. The Democrats knew that action of this sort would ultimately be sucessful and were just playing for time.

However, the resolution was referred to a committee on Federal relations. Subsequently the report of the committee came back. While the majority report was written by a Republican, the resolution's passage was not recommended at this time, although its great advantages and moral value were placed on record.

\section{Democrats Discuss Broad Issues}

In the minority report, written by Rep. Harvey Dunlavy, Democrat of Davis county, it was agreed that the resolution should be postponed. However, Rep. Dunlavy went further and discussed the Civil war and Rebellion. In his report it can be safely presumed that Dunlavy was speaking for all his fellow Democrats. He opened his report by referring to the committee as "having under consideration certain resolutions concerning the Rebellion and Civil war now unhappily existing in the country, the causes which have brought this great calamity upon the nation, and the means best calculated to restore it to its former position and prosperity.",

\footnotetext{
${ }^{41}$ State of Iowa, House of Representatives, House Journal of the Ninth General Assembly, (Des Moines: 1860), 62.

${ }^{42}$ Ibid., 142.
} 
Then Dunlavy went on to report the feasibility of such a state law as emanicpation of Negroes, reaching the conclusion that it was not ripe for passage. He then outlined the causes of the Rebellion. In his first argument, he claimed that Iowa, as well as the other northern states, was against the return of fugitive slaves, "as provided by the constitution and the laws made in pursuance thereof, and as interpreted by the courts." ${ }^{43}$ Secondly, this representative from Davis county claimed that many were "against apportionment by which the slaves of the South are represented in congress." ly, he referred to the northern assaults upon the supreme court of the United States because of the Taney decision in the Dred Scott case. In his fourth argument, Dunlavy referred to the raid of John Brown into the state of Virginia, claiming that it was an actual war upon that government.

Summing up his arguments, Representative Dunlavy claimed that the southern states saw "that there was not a single case of arrest where these men combined in the northern states to commit these offenses against the peace and good order of the country. The people of the South grew alarmed at this bad faith, and the wicked and ambitious men amongst them made it the pretext for the formal secession of the southern states from the Union, and their declaration of independence." 45

The reasoning of Representative Dunlavy was typically that of a southern Democrat, although it may have been modified somewhat for presentation in an Iowa legislative assembly. In understanding his motives, one need only note that in the county that elected him, twentythree per cent of the population had been born in the South, and others with sympathy for the southern point of view were numerous enough to assure his election in 1862. 


\section{SOUGHT TO BAR THE NEgROES}

Another incident which deserves mention also occurred in this same Ninth General Assembly which convened January 12, 1862. During the month of February, Democratic Rep. W. E. Wetherall of Marion county, sponsored a resolution which in tone would probably never have been sponsored by the most anti-Negro area in the United States. The resolution read: "Resolved, That the Committee on Constitutional Amendments be instructed to inquire into the expediency of so amending the constitution as to prevent the ingress of Negroes and mulattoes to this state, and report at an early day such provisions if it shall be deemed expedient." ${ }^{* 6}$ This resolution was not in agreement with the southern point of view, but it can only be interpreted as an attempt on the part of Iowa Democratic representatives to express sympathy for the Democrats of the South.

Rep. W. C. Woodworth, Republican from Henry county, quickly took up the cause of the Negroes and moved that the resolution of Representative Wetherall be indefinitely postponed. Upon this question a vote was taken. All those who voted "yea" were Republicans. The "nays" were Democrats plus a few Republicans, namely, T. G. Stevenson of Lee county, W. Williams, Des Moines county, John Wasson and Louis Hollingsworth of Keokuk county, Newton Guthrie of Warren county, Alfred Hood of Madison county, W. J. Moir of Hardin county, H. M. Martin of Iowa county, George A. Walton of Greene county, and Isaac Pendleton of Woodbury county. At this particular juncture, one is quick to notice those Republicans supporting the Democrats to place the abovementioned resolution for consideration by a committee for constitutional amendments were for the most part elected from counties with high percentages of southern sympathizers. ${ }^{47}$

After the Ninth General Assembly in 1862-63, with the decline of the Democrats in the house of representa-

46Ibid., 187.

${ }^{47}$ Ibid. 
tives, and after the election of Republicans from southern counties, there appeared a tendency for these Republicans to take up the Southerners' viewpoint as in the instance noted above. Sometimes these Republicans even isolated themselves from their fellow party members who were elected from those counties having more Union sympathizers. The influence of southern sympathizers still had to be reckoned with.

Early in the session of the Tenth General Assembly, during February, 1864, Mr. McNutt, Republican representative from Muscatine county, introduced House file 19. This was "a bill for an act to repeal chapter 72, of the acts of the Third General Assembly of the state of Iowa, entitled an act to prohibit the immigration of free Negroes in this state." ${ }^{48}$ Republican Rep. Samuel A. Russell of Washington county, in order to kill the bill, moved to shelve it.

Upon taking a vote for the proposal to shelve it, all five Democrats in the house voted "yea." These Democrats were backed by Republicans from counties where people of Southern origin were prominent. It is interesting to note what areas these Republicans were representing. For instance, Bell was from Pottawattamie county; Campbell from Mahaska; Buckham from Fremont county; Cort, Christoph, Richards and O'Brien from Dubuque; Hildreth from Floyd; Horton from Appanoose; King from Harrison; Russell from Washington; Oliver from Monona; Paulk from Allamakee and Sturgis from Fayette. The remaining Republicans voted "nay," with the exception of a few from the southern counties in Iowa, who either absented themselves or were not voting. Needless to say, the motion to shelve did not carry. The repeal was soon passed.

This decision, as well as the bill, represented a certain amount of confusion and, hence, it is difficult to identify clearly the northern and southern points of

${ }^{48}$ State of Iowa, House of Representatives, House Journal of the Tenth General Assembly, (Des Moines: State of Iowa, 1864), 86. 
view. It is true, nevertheless, that the southern point of view continued to assert itself locally.

\section{RELIEF FOR SOLDIER'S FAMILIES}

Governor Stone, who took office January, 1864, submitted a good illustration of this local southern point of view in his inaugural address. Governor Stone referred to an act passed by a special session of the General Assembly of 1861, which granted power to the board of supervisors in each county to appropriate money from the county treasury, which in turn was to be used for the support of soldiers' families who lived within their respective counties. Commending the act as it stood on paper as much-needed patriotic legislation, he, nevertheless, did criticize the failure to accomplish its objective. Governor Stone went on to say that in counties where these boards of supervisors were pro-Union or anti-slavery aid to soldiers' families was carried out very effectively, and suffering alleviated. However, there were many counties where the board of supervisors was composed of men who were of pro-slavery sentiment and they failed to make the act effectual. Where this situation existed, these boards "have persistently refused to appropriate a single dollar to this humane and Christian purpose."

Governor Stone named these men as of the opposite political party, here giving the impression that the Republican party completely supported the federal government in its war effort, whereas, the Democratic party was hindering that objective. In order to offset this situation, Governor Stone recommended that the state of Iowa appropriate the money which was to come from state revenue. The handling of these allotments was to be done by the agencies of the state sanitary commission, not by county boards of supervisors.

Obviously, what Governor Stone wanted was to take this power of handling soldiers' allotments out of the 
hands of the Democrats, considered too pro-slavery to be trusted. By putting the power into the hands of the state sanitary commission, the governor would retain the ability to enforce the act as he saw fit. The local agencies under the commission, of course, were politically appointed positions which would give even further assurance that the act would be enforced in the way the governor desired. He may have had a further reason for placing the authority in the hands of the sanitary commission, which was that the commission could work in better coordination with the Federal sanitary commission. However, his action is pertinent here, because he sought to take the power out of the hands of southern sympathizers, who, he believed, still had influence in much of southern Iowa. Subsequently, this recommendation was duly passed for it had the support of most of the Republicans.

\section{Opposition Becomes Less EfFective}

The Tenth General Assembly had little to fear from opposition to any Republican-sponsored legislation. With five Democrats in the house and, at most, only a few wayward Republicans, the anti-slavery Republicans were in the majority and were able to pass almost any legislation they wanted.

Opposition was voiced only on smaller matters which did nothing more than show where each representative's sympathies lay. One such matter was over the proposal to locate an arsenal at Des Moines, made by Republican Representative Andrews..

All the Democrats and some of the Republicans from southern counties voted against it. The bulk of the Republicans were for it and it passed. The implications were plainly seen that those who did not want to help the war effort to any extent were against it.

It is clearly seen in the evidence which has been presented that the Southerner not only came to Iowa but 
also made his position known. He spoke, telling not only Iowa, but the rest of the nation how he felt over this whole slavery question.

It was largely through the efforts of the Southerner that the parties in Iowa were drawn poles apart. The Southerner was responsible for southern sympathizers being sent to the state general assembly. Here the state government functioned with both abolitionists and southern sympathizers crowding the Eighth, Ninth and Tenth General Assemblies with bitter feelings on both sides. Embarrassments were endured on both sides but no one suffered more embarrassment than the state of Iowa itself. In the eyes of most of the abolitionist north, the political wrangling of Iowa was a spectacle of which to be ashamed. These Southerners in Iowa did not hesitate to pursue their objectives. Where these objectives were not attainable by peaceful methods, belligerency was occasionally resorted to.

\section{III}

\section{THE SOUTHERNER IN IOWA ACTS}

It has been shown to what extent Southerners had settled in Iowa prior to the Civil war, and how they expressed their continuing sympathy for southern views. In recapitulation, one may say that although southernborn only averaged about ten and one-half per cent of the Iowa population, they averaged higher in the southern half of the state and, consequently, were able to send to the state legislature representatives who expressed their views. Their sympathies are to be found in the records of the state legislature.

During the years when the Southerner moved northward, he was in most respects a typical settler. In 1861, under the stress of southern secession, he gave expression to his sympathies and soon resorted to overt acts designed to obstruct the majority program of assistance to the Federal cause. Some southern born people living in Iowa preferred the Republican nomination of Abra- 
ham Lincoln over Seward for the presidency. This was because they believed Lincoln was not an abolitionist. ${ }^{51}$ Many of these Southerners living in the North fought with the Union forces to keep the Union together and not to abolish slavery. ${ }^{52}$ Some Union soldiers of southern extraction fought valiantly, but they did so not as abolitionists nor as advocates of the post-war reconstruction program. Not all the people of Iowa of southern nativity, and not all of the Illinoians, Indianans, and Ohioans of southern lineage living in Iowa were thoroughly antiUnion in their sentiments. It was only a portion of the group that was inclined to take a vigorous stand of opposition. When Lincoln's intentions of abolishing slavery began to be evident, the Southerner living in Iowa was disappointed to find that his adopted state was ready to move on the road to abolition.

When Republican agitation in the state legislature began to take the initiative and support the federal government in the passage of pro-Negro and similar legislation, the Southerner in Iowa was ready to act. Feeling that he could no longer stand by and be enveloped by abolitionists, he decided to act in ways more concrete than protests in the legislature. These Southerners, relying on the Dred Scott decision, honestly and sincerely believed that northern agitation was actually directed against the constitution of the United States.

Difficulties facing Iowa in supporting the war effort, coupled with successes for the rebel forces as at Bull Run, all strengthened the Southerners of Iowa in the belief that the Confederacy had the right philosophy and solution to the slavery question.

During the war years, from 1860 to 1865 , many of these southern sympathizers living in Iowa expressed their opinion of the rebellion in various ways. Many tended to act within the organization known as the "Knights of the Golden Circle." Members of this pro-

51Des Moines Sunday Register, April 18, 1926. Professor Herriott discusses this problem in an article in the quoted newspaper.

s2Ibid. 
southern organization were a rather highly and wellfunctioning band. It was believed that they were organized and instructed by agents from the states in secession. The "Knights of the Golden Circle," in February, 1863, was said to be organized in every township in the state and to have had as many as forty-two thousand members. $^{63}$

The purpose of this organization, and for that matter of every individual southern sympathizer in Iowa, was best stated in a letter from Governor Kirkwood of Iowa to Secretary of War Stanton on March 8, 1863. Here Governor Kirkwood refers to it as "widely spread through the state, the object of which is to embarrass the government in the prosecution of the war, mainly by encouraging desertions from the army, protecting deserters from arrest, discouraging enlistments, preparing the public mind for an armed resistance to a conscription, if ordered, and, if possible to place the state government at the next election in the hands of men who will control it to thwart the policy of the administration in the prosecution of the war."

The purposes of the "Knights of the Golden Circle" represented a cross section of the feelings of the southern sympathizers in Iowa, whether members of this organized conspiracy or not. Many were not "Knights"; nevertheless, they acted in much the same way and usually their actions were spontaneous.

\section{HeNRY Clay DeAN's ACTIVITIES}

One of the most active members of the Copperhead movement was a prominent southern Iowa political personage, Henry Clay Dean. One of his speeches will give one an idea of the convictions of this man and his followers. His southern viewpoint publicly expressed, has been preserved by an Iowa historian as follows:

58D. E. Clark, Samuel Jordan Kirkwood. (Iowa City: State Historical Society of Iowa, 1917), 267.

${ }^{54}$ H. W. Lathrop, Life and Times of Samuel J. Kirkwood. (Iowa City: State Historical Society of Iowa, 1893). 
It was a war of states, with all its attendant evils, in which the government was guilty of usurpation. Lincoln tore up the constitution and set up his arbitrary will instead. Lincoln selected the weakest, worst and most corrupt men in the country, who served him cheerfully as instruments of usurpation. Lincoln dissolved the government and left the country in anarchy. Lincoln corrupted one part of the church to engage in warfare with the other part, and burned 1,200 houses of worship; he mutilated graveyards, and left whole cities and churches in ashes; dragged ministers from their knees in the very act of worship; tied them up by their thumbs; had their daughters stripped naked by Negro soldiers under command of white officers.

Henry Clay Dean was an active Copperhead who went about the countryside of Iowa pouring forth his prosouthern words on such issues as the war bond drive which was needed to support the expenses of war. His speeches discouraged enlistments and urged the disregard of the conscription act. ${ }^{\text {t5 }}$

Treasonable thoughts were harbored by many who took no active part in Copperhead movements. One such illustration involved a very notable Iowan. George W. Jones had the reputation of being instrumental in the establishment of the Territory of Iowa. He served as a United States senator from Iowa between 1848 and 1859 at which time he was succeeded by James W. Grimes. On May 17, 1861, he was reputed to have written to his friend Jefferson Davis: $:^{50}$

expressing his sympathy with the Confederate cause and with slavery as an institution, and his antipathy to the administration of President Lincoln. He also related the story of his own wrongs, as a slave holder who had been compelled by public opinion to emancipate nine slaves during his residence in the North.

Strong expressions of sympathy for the South, coupled with intercepted letters from Jones to Jefferson Davis, prompted Secretary of War Stanton to order the arrest of Jones. "After an imprisonment of sixty-four days in Fort Lafayette, New York, Jones was released by order of President Lincoln." ${ }^{57}$

55 B. F. Gue, History of Iowa (New York: Century History Co., 1903), II, 82, 85 58Johnson Brigham, Iowa, Its History and Its Foremost Citizens (Chicago: S. J. Clarke Co., 1915), I, 182. 
Prior to the outbreak of the Civil war, Jones had written to Davis as follows :55

May God Almighty avert Civil war, but if unhappily it shall come, you may, and I think doubtless would count on me and mine, and hosts of other friends standing shoulder to shoulder in the ranks with you and our other southern friends and relatives, whose rights, like my own, have been disregarded by the abolitionists. The dissolution of the Union will probably be the cause of my ruin, as well as that of my country, and may cause me and mine to go south.

With men of such standing within Iowa sharing such views, it is no wonder that many of Iowa's citizens were led to adopt similar convictions.

They worked through the "Knights of the Golden Circle" and other Copperhead ${ }^{58}$ organizations. Meetings were held quite regularly and many resolutions were passed. Each township, city, or county had to some extent one such type of lodge, but not all southern born or people of southern extraction were members of these lodges. Many were, but most of those who were not shared and harbored the same feelings and sympathies; they were aroused by the same passions. Early in 1863, at a meeting in Pleasant Ridge schoolhouse in Wapello county, a large group of Copperheads made clear their position by resolving "that we here deliberately and firmly pledge ourselves, one to the other, that we will not render support to the present administration in carrying on its wicked abolition crusade against the South; that we will resist to the death all attempts to draft any of our citizens into the army."

Adams township in Mahaska county, was not without its share of Copperhead resolutions. A series of three resolutions were passed by a meeting of Copperheads

\footnotetext{
${ }^{57}$ Cyrenus Cole, Iowa Through the Years (Iowa City: State Historical Society of Iowa, 1940), 301

58 James Truslow Adams and R. V. Coleman (ed.), Dictionary of American History (New York: Charles Scribner's Sons, 1940), II, 57-58, states the term Copperhead was "used to describe Democrats opposed to the War policy of Lincoln. The term Copperhead first appeared in the N. Y. Tribune for July 20, 1861, and within a year was common." "Generally described as treasonable, the Copperheads, or Peace Democrats, advocated a union restored by negotiation rather than war. They denounced military arrests, conscription, emancipation and other war measures."

${ }^{59}$ Daily Gate City, April 10, 1863.
} 
which termed their pro-southern gathering as a "Democratic meeting." The first resolution read "that we will oppose the further prosecution of the war under the present abolition conquest policy." The second was: "resolved that we are in favor of an armistice and a speedy national peace convention." The third resolution claimed "that we regard the conscription bill as unconstitutional, uncalled for, and that we are under no legal obligations to submit to its effect."

At a disloyal peace meeting in Davis county, composed of Copperheads, one William A. Rankin proposed resolutions declaring the war "a wicked abolition crusade against the South; that the draft should be resisted to the death; that free Negroes brought into Iowa should be driven out, and those who brought them be driven with them, or given hospitable graves." ${ }^{\circ 1}$ These resolutions were adopted by the Copperheads unanimously.

\section{OVERT ACTS OF DisLOYALTY}

As has been mentioned previously, pro-southern sentiment was fairly quiet until the state government began feeling the pinch of war, and abolition became the watchword for Union forces. Overt acts began to appear early in 1862. One such disloyal occasion occurred in Keokuk, August, 1862. A John G. Floyd, a member of the engineer corps, was charged with having a Confederate flag wave from his windows. When asked if he had disloyal Union feelings, he made no denial of it. $\mathrm{He}$ did not even pretend to be a Union man. The newspaper account went on to say that "all true Union men in the north are known. Their patriotism speaks out, and is heard by all. It is needless for any man to deny the waving of flags, - a man against whom such a charge would receive credence, has never avowed himself on the side of his country-is undoubtedly a traitor in feeling, however clearly he may have avoided a treasonable act. His explanations do not appear to have been par-

${ }^{61}$ Ibid. H. M. Byers, Iowa in War Times, (Des Moines: W. D. Condit \& Co., 1888), 266. 
ticularly satisfactory to a meeting of the loyal citizens over which Judge Lowe presided, which appears to be disposed to look sharply after this 'neutral' gentleman and kindred spirits." ${ }^{\prime 2}$ When charged with Southern sympathy and brought to trial, he never once spoke with pro-Union sentiment.

Another illustration of how Southern sympathizers were able to help the Confederate cause occurred in Keokuk also. It seems that some Missourians made a raid from Alexandria, Missouri, into Iowa with the intent of capturing Keokuk. The people of Keokuk received warning of this impending raid and prepared to surprise the rebels. Having dug in and made fortifications, they probably could have wiped out the raiders. However, a southern sympathizer by the name of Ray left Keokuk and proceeded to warn the rebels from Missouri. This probably saved the day for the Missourians who quickly and discreetly dispersed. Subsequently, Ray was taken by pro-Union men and given a good beating as punishment. $^{.3}$

There was such a rise of secessionist feeling in Keokuk that one Major Torrence of the Home Guards issued an order that even the slightest ill feeling toward the Union should be reported to him at once. In his General Order No. 2, he asked that his guards form themselves in small groups and investigate any place where disloyal sentiment might be suspected. Where such was the case, it was to be reported to him at once. ${ }^{.4}$

\section{"The TALLY WAR"}

When considering to what extent feeling ran for the southern point of view, one is quickly reminded of "The Tally War," which took place in Keokuk county. In such communities where large numbers of Southerners lived, only a slight incident was required to arouse the mob spirit and produce serious disorder. This was the

${ }^{62}$ Burlington Daily Hawkeye, August 6, 1862.

'Ibid, August 6, 1863.

C4Ibid, August 14, 1862. 
case in South English in Keokuk county. August 1, 1863, proved to be a day which almost produced a miniature Civil war. The Copperheads in this southeastern community were numerous. These southern sympathizers were led by one Rev. George C. Tally, who was outspoken in his denunciation of the government. Many of the pro-Northerners were opposed to Tally and his followers. This did not matter to Tally as it is claimed he made the statement that he was going to clean out South English of all northern sympathizers.

On this fateful day of August 1, 1863, in South English, a Republican meeting was held. ${ }^{95}$ It was attended by pro-Northerners who carried weapons for protection against the threats of the Copperheads. During the meeting, Tally and his followers approached the town in wagons. Tension prevailed and Tally was warned not to enter the immediate area. However, he was allowed to pass through the area when he assured all that he meant no harm. In the center of the town, the proNorthern Republicans began to shout remarks such as "coward" and "Copperhead." A gun was accidentally fired and immediately Tally and his followers drew weapons which were hidden in the wagons. Tally himself was armed with a pistol in one hand and a bowie knife in the other. Being one of the first to fire, he was a principal target. After having fired twice, he was dropped with three bullets, one through his head and two through his body. Two or three others were wounded. But here this small war stopped.

Nevertheless, Tally's followers quickly left the town and swore vengeance. Southern sympathizers from Keokuk, Wapello, Mahaska and Poweshiek counties soon met on the western border of Keokuk county and excitement prevailed for a few days. However, word was gotten to Governor Kirkwood who quickly dispatched some companies of the militia to the scene. More bloodshed was

${ }^{65}$ Dan E. Clark, Samuel Jordan Kirkwood (Iowa City: State Historical Society of Iowa, 1917), 270-271. 
averted when the Copperheads dispersed upon seeing the state troops.

\section{Disloyal ACTS Bold AND OPEN}

In Washington county, a Joseph Swisher, Philander Swisher, William A. McCoy and A. Dillon were taken into custody by the sheriff for having aided a Southerner. It seems that a pro-Union war meeting was called in a precinct in Washington county by an army recruiting officer named William Burgess. The meeting was well attended. A man named Landerbaugh during the meeting kept annoying the speakers by hurrahing for Jefferson Davis. Landerbaugh, being of Southern origin, threatened rather frequently during the speech that he would walk in the blood of those present who had taken an active part in getting up the meeting. A complaint was filed against Landerbaugh and he was arrested and taken to Brighton. On the road both Swisher brothers, McCoy and Dillon, also of Southern origin, rescued Landerbaugh and freed him. However, the four accomplices were arrested and brought before the provost marshall of the district who quickly had them sentenced. ${ }^{e \theta}$

In this incident, it was evident that the Southern sympathizers were bold enough to act openly. Their behavior, though spontaneous, showed their deliberate intent to stick together in maintaining their position.

Similar disturbances occurred in a county such as Muscatine with only seven per cent of southern-born population. It seems that an alderman by the name of William C. Kennedy was arrested on a charge of discouraging enlistments. He was subsequently taken to Davenport, where he boasted that he had owned the "Palmetto Saloon" in St. Louis and was the first man to raise the secession flag in that city. It seems strange that a Missourian such as Kennedy and with such sympathies would be elected alderman in a county with a

${ }^{6} I$ Ibid, August 15, 1862. 
low percentage of southern born, unless that county was secretly infiltrated with many people of Southern extraction. ${ }^{67}$

Iowa City, in Johnson county, was not without its share of Southern sympathizers. After many complaints that all too many people were engaged in the intrigue of offering money to recruits or prospective recruits either to leave or not join the service, an arrest was made. The accused had engaged in this sort of antiUnion agitation and had spent an undisclosed small fortune in his endeavors. ${ }^{.8}$

\section{USED NEGROES AS THREAT}

The Burlington Daily Hawkeye on October 2, 1862, gave a very good account of an incident which took place in that city. The newspaper claimed that certain secessionists and pro-Southerners were telling the laboring people of the city that, if they did not vote proSouthern candidates into all offices, the Negroes would soon have their jobs. The paper went on to accuse the parties involved of stirring up pro-rebel sentiment as the Negro warnings continued even after elections. The newspaper discredited this report, pointing out that there were no more than a dozen Negroes in Burlington. The newspaper charged that it was all a trick designed to divide pro-Union sentiment. ${ }^{\circ}$

Disloyalty in Fremont county was evident as was shown during a pro-Union meeting in April, 1863. The disloyalists, led by one Mr. Prosser, walked into the meeting with the intention of breaking it up. These southern sympathizers were successful, but not before a Federal sergeant, who had attended the meeting under orders to arrest some deserters, was killed. ${ }^{70}$

The Fairfield Ledger gives an account of another shooting. It seems that a deserter from the Union forces was being housed by a Copperhead. A United

${ }^{67}$ Ibid., August 16, 1862.

B8Ibid, August 20, 1862.

9rIbid, October 2, 1862.

70 Keokuk Gate City, April 25, 1863. 
States officer, having learned where the deserter was hiding, proceeded to make the arrest. The Copperhead, to protect his escape, fired a shot at the officer with the intention of killing him. Fortunately, or unfortunately, it missed him but hit a little girl killing her instantly. The man, not identified by the newspaper, was said to have been an active member of the "Knights of the Golden Circle." The murderer was eventually apprehended and taken to Keokuk for trial. ${ }^{\text {" }}$

Appanoose county, with twenty-two per cent southernborn population, had its share of Copperhead threatenings. A mob threatened to drive a respectable citizen from the country because he was on the verge of giving employment to a Negro. Taylor county also had similar threats. Many Negroes who escaped their masters from Missouri, took up residence in this Southern county. Copperhead mobs went about exposing these escaped Negroes and threatening anyone who gave them residence. $^{72}$

On June 26, 1863, in Linn county, an anniversary celebration of Cornell college at Mount Vernon was being held. Copperheads thronged the area, wearing badges indicating their sympathies. Because of the boldness which these men showed, proceedings were stopped and about 2,000 pro-Union people threatened them if they did not remove the badges. Most of them did without hesitation. However, a particular man and woman refused to heed the warning. The man was apprehended first, and choked until he promised to obey the command. The woman ultimately obeyed the orders. Most of the southern sympathizers were then rounded up and made to yell hurrahs for the Union. Six touble-making Southerners were taken in custody to stand trial. However, they were released for lack of evidence. ${ }^{\text {ts }}$

A very unfortunate incident occurred in Mills county in 1863. A family by the name of Fallon moved from

7 Fairfield Ledger, May 11, 1863.

${ }^{72}$ S. H. M. Byers, Iowa in War Times, (Des Moines: W. D. Condit \& Co., 1888), 266.

${ }^{73}$ Muscatine Daily, July 15, 1863. 
the South and settled a few miles east of Glenwood. The family consisted of a mother, father, and several children, among whom was a son called Joe. These Fallons were rather well liked in the community, except that most of the Unionists of the town feared that they still harbored all the prejudices of the South.

One day in the fall of 1863, Joe Fallon found himself walking about the streets of Glenwood. As he passed by a flagpole, the sight of the Union flag infuriated him and pulling out a revolver he began to shoot at it. A radical Unionist by the name of James A. Nelson happened to be near Fallon and immediately struck Joe upon the head with a crutch. Within a moment a crowd. gathered and to prevent a lynching, level heads decided to conduct a trial. A committee was formed of loyal men of the community to try Joe and then determine his punishment. After many suggestions, it was finally decided that Fallon should be made to kneel on the floor and take an oath of allegiance to the United States. He was to be fined approximately $\$ 250$ which was to be distributed among the needy families of soldiers.

After complying with the provisions of the punishment, he was told to get out of town and never return. This Joe Fallon did, as he was not seen or heard from afterward. ${ }^{74}$

Again in the autumn of 1863, Fremont county was threatened with disorder and violence. On October 30, Provost Marshal Van Eaton and a few deputy marshals took after some suspected Copperheads on the road to Sidney. Van Eaton and his party were ambushed from the roadside and Van Eaton murdered. Very soon after, Sidney's fine courthouse was blown up, presumably by these same desperadoes. ${ }^{75}$

\section{Ottumwa Area a Trouble Center}

Ottumwa in Wapello county was considered to be an area filled with Copperheads and southern sympathiz-

\footnotetext{
74J. D. Edmundson, "In Honor of the Flag," The Palimpsest, VI, (Iowa City: May, 1925), 141-145.

๘ॅ. H. M. Byers, Iowa in War Times, (Des Moines: W. D. Condit \& Co., 1888).
} 
ers. A clash between southern sympathizers and proUnionists occurred on August 9, 1864. A man by the name of Fouch paraded the streets of Ottumwa wearing Union badges. He had been suspected of Copperhead feelings, yet no one ever had any tangible evidence against him. However, this particular August 9, 1864, Fouch, though wearing Union badges, started to declare aloud that the governor and the government amounted to nothing. A wounded Union soldier tore Union badges from Fouch and began struggling with him. The Copperhead managed to escape. Subsequently, he reappeared wearing another Union badge. Word had gotten around by this time and quickly a crowd gathered about Fouch. One William J. Hamilton began giving Fouch a good drubbing. Immediately the latter drew a revolver. However, it was taken from him, whereupon his mother drew a revolver. The women of the town wasted no time in taking her in hand. Both Fouch and his mother were then told by northern sympathizers that there was not any room in town for Southerns who acted against the Union. The family immediately packed and was not heard from again. ${ }^{78}$

Madison county in 1864, experienced a fracas that caused much excitement. It seems that in September, that year, two Union soldiers returned from the front to their home in Union township. Upon their arrival, they were quite surprised over finding so many southern sympathizers so outspoken. Determined not to see their work at the front undone, they decided to clean out the Southerners. They started on a Copperhead who was accused of hiding two rebel soldiers. The two rebel soldiers were found and taken to the woods to tell what their business was in Madison county. The Copperhead was given a beating and released. Subsequently, the two Union soldiers were joined by a group of other Unionists who had just returned from Winterset, where a meeting of the "Knights of the Golden Circle" was broken up. The Unionists together went to the homes

${ }^{78}$ Burlington Daily Hawkeye, August 13, 1864. 
of suspected Copperheads where warnings were given. One family of Southerners was even ordered out of the area within twenty-four hours. ${ }^{77}$

\section{OFFICERS ATTACKED AND MURDERED}

Sugar Creek township in Poweshiek county was not without its murders. The area was known to harbor Southern sympathizers, scoundrels and murderers. The area Provost Marshal James Mathews, sent two officers, Josiah N. Woodruff and John L. Bashore, into Sugar Creek to arrest some deserters. On the road to Oskaloosa, about fifteen miles south of Grinnell, the officers were attacked and murdered. Woodruff's body was brutally filled with bullets. Bashore's brains were literally beaten out with the butt of a gun. The affair aroused the Unionists to a point of wanting to lynch all southern sympathizers. However, cool judgment prevailed and the assassins were eventually brought to trial, where they were sentenced to pay for their crimes. ${ }^{78}$

There were other brutal murders of Union men occurring at the same time. One such occurred within Davis county. Disguised in Federal uniforms, twelve Copperheads entered the county on October 12 . They robbed and murdered farmers recklessly. Whenever a Union soldier was found, he was immediately shot by these disguised Copperheads. ${ }^{70}$

Sympathy with southern feelings was expressed elsewhere and in other forms. Such was the case at Eddyville in Wapello county. After President Abraham Lincoln was assassinated, many Copperheads went about expressing their feelings that it was for the good of the country. One such southern sympathizer of Eddyville expressed his opinion that Lincoln should have died four years earlier. Quickly a mob gathered about him and

77P. W. Black, "Lynching of Iowa," Iowa Journal of History and Politics. X, (Iowa City: 1912). 266.

${ }^{78}$ S. H. M. Byers, Iowa in War Times, (Des Moines: W. D .Condit \& Co., 1888),

79Ibid. 
whipped him until he was nearly dead. Half dead he was ordered to leave the country. ${ }^{80}$

In Guthrie county a lady of southern origin asserted that Abraham Lincoln got what he deserved, for he paid for the sins he committeed against the South. Local reaction to her remark was not recorded..$^{81}$

A very similar situation occurred in Lee county. A Copperhead by the name of Henry Mitchell had been voicing displeasure with the federal government. At the time of Lincoln's death, he was heard to remark that it was the best thing that could have occurred. Union soldiers caught Mitchell and managed to get revenge for the Union. With bells and Union flags on him, he was made to parade the streets of Fort Madison. A crowd gathered and enjoyed the spectacle. Later he was taken to the depot, put on a train, and sent away. ${ }^{82}$.

Mason City in Cerro Gordo county had its share of pro-Southern and anti-Lincoln feeling. April 18, 1865, one Mary Regan, a southern sympathizer, was heard to shout "they say Lincoln has been shot. I hope to God its true and I hope my brother shot him." 83 Words of this sort were next to committing suicide in a county of such strong Unionist feelings. Women with husbands, brothers and sweethearts fighting and dying for the Union would not let such a statement go without punishment. A crowd of women quickly gathered about Mary Regan's house and proceeded to get her out and parade her down the streets of Mason City. She was taken to Willow creek and thrown in head first. One woman in the crowd was heard to remark "my husband is fighting rebels south and we will attend to them here."

Though these murders and robberies sound brutal, they, nevertheless, were closely related to the Copperheads. S. H. M. Byers stated that "all these outrages

${ }^{5}$ Daily Iowa State Register, May 4, 1865.

s1Daily Iowa State Register, May 13, 1865.

82Ibid., May 5, 1865. 126. ${ }^{84}$ Ibid. 
and murders in Iowa in 1863-64 were the result of Copperhead teachings, and when not committed by them directly, they were committed by their associates and allied outlaws from Missouri.",ss

\section{MILITIA USED BY KIRK'WOOD}

As the war progressed and approached its closing stages, the pro-Southern incidents became less vehement. Finding themselves less numerous than during the earlier years of the war, southern sympathizers were disinclined to run as many risks. Governor Kirkwood met the threats of southern sympathizers with the state militia which was organized in every southern Iowa county. $\mathrm{He}$ asked and obtained from the Federal government a general officer, namely, Brigradier General Roberts. The state was organized into a military district, and martial law was strictly enforced. Serious incidents were handled not only by the state militia but also by Union soldiers. However, when the war was over, the southern born in Iowa were blended with the rest of the population and were no longer regarded as a separate class. After having come to Iowa, speaking their minds and acting for the fulfillment of their sympathies, the Southerners in Iowa at the close of the Civil war, were willing to accept the consequences. They were now willing to get down to business and work, becoming first Iowans and eventually Unionists.

With the conclusion of this survey, it is clear that the Southerner not only came to Iowa, but came in sufficient numbers to make his influence felt. Though southern born in Iowa in 1860 numbered but 54,006, the figures were, nevertheless, supplemented by that undetermined number of Illinoians, Indianans, and Ohioans who traced their ancestry back to the South. Though these three states sent 162,847 to Iowa ${ }^{80}$ it is impossible to determine how many were of southern lineage or point of view. The fact that the southern point of view was

${ }^{85}$ S. H. M. Byers, Iowa in War Times, (Des Moines: W. D. Condit \& Co., 1888). ${ }_{88}$ Compiled from county totals in the 1856 Iowa census records. 
voiced to an appreciable extent in the Iowa General Assembly suggests that out of the 162,847 from Illinois, Indiana and Ohio, a very considerable proportion must have maintained sympathies for the South. Though these southern sympathizers never had a control of the Iowa General Assembly, they, nevertheless, caused great embarrassment to the abolitionists of the North. At times when this same group felt they were losing the battle in the legislature, they resorted to overt acts. While some of these demonstrations were spontaneous outbursts, others were conducted by organized groups. All had the common objective of embarrassing the northern proUnion government, and to help the Confederacy of the South realize its aims.

However, when the Civil strife came to a close, these same Southern sympathizers in time became so well integrated in Iowa that today one never considers that the state was other than a pro-Union state. This may account for the fact that Iowa has always been considered traditionally a northern state.

\section{GOVERNOR CARPENTER'S TRAITS}

In 1853, while J. C. Savery was keeping hotel in Des Moines at the old Hoxie stand on Third street, C. C. Carpenter, then young and unknown, came to Fort Des Moines on his first tour to the west, in search of a school. After sojourning for a time with Mr. Savery, and failing to obtain a school here, took up his satchel, and wended his tedious and weary way to Fort Dodge, eighty-five miles, as a pedestrian. It is hardly probable, while achieving his laborious journey on foot, that the young imigrant looked forward prophetically to the time when he would become governor of a great state, with more than a million inhabitants. Such is fate, or rather, such is grit, pluck, brains, and a superintending Providence.-J. M. Dixon in History of Polk County. 
Copyright of Annals of Iowa is the property of State of Iowa, by \& through the State Historical Society of Iowa and its content may not be copied or emailed to multiple sites or posted to a listserv without the copyright holder's express written permission. However, users may print, download, or email articles for individual use. 